\author{
Микола Галів, \\ доктор педагогічних наук, доцент кафедри історії \\ України, \\ Дрогобицький державний педагогічний університет \\ імені Івана Франка \\ (м. Дрогобич, Україна) \\ Mykola Haliv, \\ Doctor of Pedagogical Sciences, Associate Professor of \\ the Department of History of Ukraine, \\ Ivan Franko Drohobych State Pedagogical University \\ (Drohobych, Ukraine) \\ halivm@yahoo.com \\ ORCID ID 0000-0001-7068-3124 \\ Researcher ID: F-3855-2018 \\ Scopus profile ID: 57212151942
}

УДК 37(091)(477.83-21):27-788-055.2

\title{
ЗМІСТ ОСВІТИ У ДРОГОБИЦЬКІЙ УЧИТЕЛЬСЬКІЙ СЕМІНАРІЇ СЕСТЕР ВАСИЛІЯНОК (1920 - 1936 РP.)
}

\begin{abstract}
Анотація. У статті проаналізовано зміст освіти в Приватній учительській жіночій семінарії сестер Василіянок 3 українською мовою навчання, яка діяла у міжвоєнному Дрогобичі. Висвітлено заснування та головні віхи діяльності учительської семінарії сестер Василіянок, схарактеризовано педагогічний колектив семінарії, з'ясовано зміст освіти в семінарії, окреслено склад студентів. Сестрам чину Св. Василія Великого (ЧСВВ) у Дрогобичі вдалося забезпечити ці заклади матеріально, організувати належний педагогічний персонал, зібрати значну кількість семінаристок та учнів. 3'ясовано, що освітній процес визначався державними програмами і планами, виховна ж робота зосереджувалася переважно на релігійно-моральному, естетичному та громадянському напрямах. За приблизними підрахунками, учительська семінарія сестер Василіянок підготувала понад 350 народних учителів.
\end{abstract}

Ключові слова: сестри Василіянки, учительська семінарія, «школа вправ», Дрогобич, підготовка учителів.

\section{THE CONTENTS OF THE EDUCATION IN THE NUNS BASILIAN'S DROGOBYCH TEACHER'S SEMINARY (1920 - 1936)}

Abstract. The relevance of the study is due to the increasing attention of historians of pedagogy to the activities of the Church and monastic orders in the field of education. Among the Ukrainian monastic orders, which carried out an active educational work, the Order of St. Basilius Magnus (OSBM) was particularly distinguished, including his female branch - the nuns Basilian. It was the nuns Basilian who organized a women's teacher's seminary in Drohobych in the 1920-ies and 1930ies. But nuns Basilian's activities have not been sufficiently studied in historical and pedagogical science.

The purpose of the article is to reveal the content of education in the Ukrainian private women's teacher's seminary of in the interwar Drohobych. The research is based on socio-cultural and lemological approaches, on the principles of historicism, systematicity, scientific. The author applied general scientific (analysis, synthesis, generalization) and specialhistorical (historical-genetic, historical-typological, historical-systemic, documentary heuristics) methods.

A foundations and main aspects of the activity of the OSBM's teacher's seminary, the level of education of the seminary teachers, the number of students, the peculiarities of the educational process in the seminary are explored in this article.

Therefore, during the interwar period, the OSBM's nuns in Drohobych actively pursued two educational institutions within the walls of the monastery - a women's teacher's seminary and an elementary school. They were able to provide these facilities financially, to arrange for proper teaching staff, to gather a large number of students and pupils. An according to my calculations, the teacher's seminary of Basilian's nuns trained more than 350 teachers, who later performed teaching duties in schools in the Drohobych region. The Basilian's six-grade (and later seven-grade) primary school also provided a good elementary education for several hundred children from poor families and orphans. The prospect of further research is to study the activity of the Basilian's women teacher's seminary in Yavoriv.

Keywords: the Basilian nuns, teacher's seminary, «exercise school», Drohobych, teacher training.

\section{ВСТУП}

Постановка проблеми. Діяльність релігійних організацій у сфері освіти привертає усе більшу увагу дослідників з огляду на роль, масштаби і вплив Церкви та чернечих орденів у житті українського суспільства на різних історичних етапах. Серед українських чернечих орденів, які провадили активну освітню працю, особливо 
вирізнявся Чин Св. Василія Великого, зокрема і його жіноче відгалуження - сестри Василіянки. У першій половині XX ст. вони виявилися одними з небагатьох, хто взяв на себе обов'язок влаштування не лише дитячих садочків (захоронок), дитячих притулків (охоронок), початкових шкіл, але й ведення учительських семінарій для забезпечення мережі народного шкільництва підготовленими кадрами. Освітню діяльність сестри Василіянки розгорнули і в Дрогобичі, що потребує окремого дослідження.

Аналіз наукових досліджень і публікацій. Починаючи з 1990-х рр. факт існування у Дрогобичі української вчительської семінарії сестер Василіянок викликав зацікавлення дослідників. У цей час з'явилися перші дослідження історика освіти Б. Добрянського, присвячені цій інституції (Добрянський Б., 1995; Добрянський Б., 2005). Його напрацювання використані науковцями і в узагальнювальних працях з історії освіти міжвоєнного Дрогобича (Тимошенко Л., 2009; Сеньків М., 2011). Дещо розширили коло опрацьованих джерел з діяльності семінарії М. Галів та І. Чава (Галів М., Чава І., 2016). Однак на сьогодні немає узагальненого дослідження змісту освіти Дрогобицької приватної жіночої семінарії сестер Василіянок.

\section{МЕТА І ЗАВДАННЯ ДОСЛІДЖЕННЯ}

Мета статті - розкрити зміст освіти в учительській семінарії сестер Василіянок, яка діяла у міжвоєнному Дрогобичі. Завдання дослідження: висвітлити заснування та головні віхи діяльності учительської семінарії сестер Василіянок, схарактеризувати педагогічний та студентський колективи семінарії, з'ясувати змістові особливості навчального та виховного процесу в семінарії.

\section{МЕТОДИ ДОСЛІДЖЕННЯ}

Студія Ґрунтується на соціокультурному та лімологічному підходах, принципах історизму, системності, науковості. Застосовано загальнонаукові (аналіз, синтез, узагальнення) та спеціально-історичні (історикогенетичний, історико-типологічний, історико-системний, документальної евристики) методи.

\section{РЕЗУЛЬТАТИ ДОСЛІДЖЕННЯ}

До Першої світової війни у Дрогобичі, як і в усій Галичині, фаховому шкільництву не надавали належної ваги. У міжвоєнний період громадськість Дрогобича намагалася виправити цей стан, відкриваючи приватні навчальні заклади професійного спрямування. Відтак у місті було відкрито дві вчительські семінарії (українська і польська), промислово-технічна школа, торгівельна школи. Власне українську учительську семінарії у Дрогобичі заснували сестри ЧСВВ, які на початку XX ст. прибули з Яворівського монастиря.

Згідно з твердженням дослідників, українська жіноча вчительська семінарія сестер Василіянок постала 1 або 7 листопада 1920 р. у приміщені монастиря сестер Василіянок на вул. Конарського, 6 (зараз - корпус музичного коледжу імені В. Барвінського) (Добрянський Б., 2005, с. 112; Тимошенко Л., 2009, с. 171). Однак, як свідчить лист ігумені монастиря Емілії Тимочків до Краєвої шкільної ради від 9 грудня 1920 р., «приватні курси учительського жіночого семінара, як також жіночу школу вправ» було відкрито 1 жовтня 1920 року. Відтак ігуменя запевняла львівських урядовців у наявності необхідних умов для ведення освітньої діяльності й просила про надання прав публічності (ЦДІАУЛ, Ф. 179. оп. 2, спр. 999, арк. 154). Дозвіл на діяльність від Міністерства віровизнань і публічної освіти Польщі учительська семінарія сестер Василіянок отримала 7 серпня 1922 р. (ДАЛО, ф.1262. оп. 9, спр. 1, арк. 2; ЦДІАУЛ, Ф. 179. оп. 3, спр. 1283, арк. 46). Першим директором став вчитель релігії з державної гімназії ім. Владислава Ягайла о. Полієвкт Кміт, опісля - Микола Байрак, о. Онуфрій Гадзевич, о. Євген Громницький, Микола Григорійчук. Усі вони мали університетську освіту (ЦДІАУЛ, Ф. 179. оп. 2, спр. 999, apк. 154; Zagyrowski Z., 1924, s. 380; Добрянський Б., 2005, с. 112).

Право публічності заклад отримав рескриптом Міністерства віровизнань і публічної освіти лише 17 грудня 1925 р. Згодом це право семінарія змогла здобути на 1926/1927 і 1927/1928 навчальні роки. Проте після перевірки закладу інспекторами Ч. Заяцем і В. Левицьким, які виявила серйозні проблеми в підготовці студенток, нестачу фахових викладацьких кадрів, відсутність кабінету для ручних робіт, недотримання формальностей при вступних екзаменах, семінарія сестер Василіянок не отримала права публічності в 1928/1929 і 1929/1930 навчальних роках (ЦДІАУЛ, Ф. 179. оп. 3, Спр. 1283, арк. 131 зв).

Освітній процес у семінарії забезпечували педагоги місцевих закладів освіти: державної гімназії ім. Владислава Ягайла, приватної гімназії ім. Івана Франка, польської приватної учительської семінарії, низки початкових шкіл Дрогобича. Станом на грудень 1920 р., окрім о. П. Кміта, який навчав педагогіки та релігії, у семінарії викладали ще 9 осіб, з них 7 мали університетську освіту. П. Кміт, А. Собчук та М. Байрак були гімназійними професорами, інші мали кваліфікацію вчителів виділових шкіл (ЦДІАУЛ, ф. 179. оп. 2, спр. 999, арк. 159 зв). У 1922/1923 н. р. підготовку семінаристок забезпечували 10 педагогів (ЦДІАУЛ, Ф. 179. оп. 3, спр. 1283, арк. 13 зв). Серед них викликає цікавість особистість Ольги Чайківської, яка здобула вищу освіту, навчаючись на філософських факультетах в університетах Львова, Граца і Відня. у 1921 р. вона закінчила ще й педагогічні курси, отримавши право вчителювати в початкових школах. Роман Смалько закінчив філософський факультет та 2 роки відвідував ще й правничий факультет Львівського університету. Математику викладав Олексій Кущак - випускник філософського факультету Віденського університету 1909 р. (ЦДІАУЛ, ф. 179. оп. 3, спр. 1283, арк. 19-20, 43).

Штат викладачів семінарії на 1924 р. складався з 11 осіб греко-католицького визнання (разом з директором), з яких два працювали у державній чоловічій гімназії (о. П. Кміт, О. Кущак), три - у приватній гімназії ім. І. Франка (М. Байрак, Р. Смалько, о. С. Венгринович), решта - у початкових школах (Zagyrowski Z., 1924, s. 380). Згідно зі звітом директора семінарії о. Є. Громницького перед Кураторією, у 1927/28 н. р. заклад мав лише двох контрактових викладачів: професора державної гімназії ім. Владислава Ягайла Генрика Пінкаса та професора польської приватної 
учительської семінарії Миколу Григорійчука. Серед викладачів були черниці Марія Ізничак (методика, педагогічна практика) та Олександра Молчко (ручні роботи) (ЦДІАУЛ, Ф. 179. оп. 3, спр. 1283, арк. 89-89 зв, 93 зв).

у 1929/30 н. р. в закладі працювало 13 викладачів, у тому числі директор Микола Григорійчук - випускник Чернівецького університету. Окружний шкільний інспектор Теофіль Козяра, відвідавши учительську семінарію сестер Василіянок у березні 1930 р., відзначив, що дев'ять педагогів були українцями, четверо - поляками. До викладачів-поляків інспектор зарахував і двох євреїв: випускника Львівського університету Симона Бієра (нар. 1904 р.), котрий навчав польської мови, та др. Марію Рейтер (нар. 1907 р.), яка п'ять років вивчала медицину у Львівському університеті (у семінарії викладала анатомію). Серед залучених викладачів-поляків слід відзначити і Софію Рейхард (нар. 1907 року), що закінчила Інститут пластичних мистецтв та два роки навчалася в Інституті ручних робіт у Варшаві, а також Анну Прехт (нар. 1898 р.), котра чотири роки студіювала у Львівському університеті та склала вчительський екзамен з німецької та французької мов (ЦДІАУЛ, ф. 179. оп. 3, спр. 1283, арк. 110-111, 118-119). Загалом сестрам Василіянкам вдавалося впродовж усього часу існування семінарії залучати найкращі в Дрогобичі педагогічні кадри для забезпечення освітнього процесу семінарії.

Характеризуючи чисельність і склад студентів української семінарії, відзначимо, що керівництву закладу вже у перший навчальний рік (1920/1921) вдалося сформувати одразу чотири курси. На першому курсі навчалося 30, на другому - 7, на третьому - 26, на четвертому - 16 семінаристок. Загальна кількість здобувачів «учительського звання» на той час становила 79 осіб (ЦДІАУЛ, ф. 179. оп. 2, спр. 999, арк. 160). Чисельність семінаристок кожного року коливалася у межах 70 - 120 осіб. Так, у 1922/1923 н. р. до семінарії записалося на навчання 99 дівчат, у 1924/1925 н. р. у закладі навчалося 117, у 1925/1926 н. р. - 88, у 1927/1928 н. р. - 105, у 1929/1930 н. р. - 69, у 1932/1933 н. р. 74 семінаристки (ЦДІАУЛ, ф. 179. оп. 3, спр. 1283, арк. 13, 55, 90 зв, 111; спр. 1284, арк. 29). Серед них переважали українки, хоча траплялися єврейки та польки. Зокрема, в середині 1930-х рр. до семінарії сестер Василіянок було переведено 30 дівчат з польської приватної жіночої семінарії (ДАЛО, ф. 1262, оп. 9, спр. 10, арк. 2-6).

Зміст освітнього процесу в учительській семінарії визначався польським законодавством. Відзначимо, що 1924 р. термін навчання у семінаріях зріс до п'яти років. Як відомо, перші три роки в п'ятирічних учительських семінаріях були призначені загальноосвітній підготовці, а два наступних - професійній. Передбачалося вивчення релігії, польської мови і літератури, іноземної мови, історії, науки про сучасну Польщу разом з наукою господарювання, географії з геологією і космографією, математики з кресленням, фізики, хімії з мінералогією, біології (ботаніка, зоологія) разом з анатомією, городництва з бджільництвом, малювання, музики і співів, а також тілесні вправи з іграми і забавами, ручні роботи, каліграфія, психологія і логіка, педагогіка. В українських приватних семінаріях до обов'язкових предметів належала українська мова, натомість іноземна мова (в Дрогобицькій семінарії сестер Василіянок - німецька) була надобов'язковою дисципліною, тобто студентки вивчали її за бажанням (Завгородня Т., 2007, с. 194-195).

у 1926 р. Міністерство віросповідань і народної освіти Польщі затвердило новий навчальний план для державних учительських семінарій з українською мовою навчання (див. таблицю 1). Приватні педагогічні заклади, бажаючи отримати право публічності, також впроваджували його у свій освітній процес.

Таблиця 1

Навчальний план для державних учительських семінарій з українською мовою навчання

\begin{tabular}{|c|c|c|c|c|c|c|}
\hline \multirow{2}{*}{ Предмет } & \multicolumn{5}{|c|}{ Курс і год / тижд. } & \multirow{2}{*}{ Разом } \\
\hline & I & II & III & IV & $\mathbf{v}$ & \\
\hline Релігія & 2 & 2 & 2 & 2 & 2 & \\
\hline Польська мова & 4 & 4 & 4 & 4 & 4 & \\
\hline Українська мова & 4 & 4 & 4 & 4 & 4 & \\
\hline Іноземна мова & 2 & 2 & 2 & 2 & 2 & \\
\hline Історія & 2 & 3 & 3 & 2 & \multirow{2}{*}{2} & \\
\hline Географія & 3 & 3 & 3 & - & & \\
\hline Математика & 4 & 3 & 3 & 2 & 2 & \\
\hline Фізика з хімією і мінералогією & 3 & 3 & 2 & 2 & - & \\
\hline $\begin{array}{l}\text { Біологія (ботаніка, зоологія, } \\
\text { анатомія, фізіологія, гігієна) }\end{array}$ & 2 & 2 & 4 & - & 2 & \\
\hline $\begin{array}{l}\text { Музика (співи, гра на } \\
\text { інструменті) }\end{array}$ & 2 & 3 & 2 & 2 & 3 & \\
\hline Фізичні вправи & 2 & 2 & 2 & 2 & 2 & \\
\hline Каліграфія & 1 & - & - & - & - & \\
\hline Рисунок & 2 & 2 & 2 & 2 & \multirow{2}{*}{2} & \\
\hline Ручні робота & 2 & 2 & 2 & - & & \\
\hline \multicolumn{7}{|c|}{ Предмети педагогічного циклу } \\
\hline
\end{tabular}




\begin{tabular}{|c|c|c|c|c|c|c|}
\hline $\begin{array}{l}\text { а) психологія і наука про дитину, } \\
\text { історія виховання і педагогіка }\end{array}$ & - & - & - & 6 & 5 & 11 \\
\hline $\begin{array}{l}\text { б) методики викладання разом з } \\
\text { педпрактикою }\end{array}$ & - & - & - & 6 & 6 & 12 \\
\hline Разом & 35 & 35 & 35 & 36 & 36 & 177 \\
\hline
\end{tabular}

Джерело: Завгородня Т. Теорія і практика навчання в Галичині (1919 - 1939 рр.). Івано-Франківськ, 2007. С. 196.

Такий навчальний план упровадила і семінарія сестер Василіянок у Дрогобичі, про що свідчить звіт директора о. Євгена Громницького за 1927 - 1928 н. р. (ЦДІАУЛ, ф. 179. оп. 3, спр. 1283, арк. 89-90).

Порівняння навчальних планів для учительських семінарій з польською та українською мовами навчання свідчить, що предмети вивчення у них були однаковими, за винятком української мови. Вона вводилася в семінаріях з українською мовою навчання за рахунок скорочення часу на вивчення фізико-математичних предметів, іноземної мови, руханки, а також шляхом збільшення тижневого навантаження на кожному курсі на 3 години (Завгородня Т., 2007, с. 197). Оскільки єдиної державної програми з української мови не існувало, то польські власті дозволяли викладачам складати тематичне планування, яке, звісно, слід було затверджувати в шкільній Кураторії. Воно давало змогу виявляти творчий підхід, уводити до програми елементи українознавства. Наприклад, у тематичному плані вивчення української мови в учительській семінарії сестер Василіянок на 1928/1929 н. р. на 4 курсі передбачалося вивчення літератури галицького відродження, діяльності Кирило-Мефодіївського братства, а до обов'язкових текстів були включені твори Т. Шевченка «Три літа», «Наймичка», «Сон», «Кавказ» (Завгородня Т., 2007, с. 208).

Навчальний процес здійснювався в семи кабінетах. у 1928 р., згідно зі звітом директора о. Є. Громницького, обладнання географічного кабінету складалося 32 глобусів, 40 настінних карт, 10 історичних портретів, атласу античного мистецтва, історичного атласу, комплекту картин до вивчення сучасної Польщі, зображень польських королів і письменників. Фізичний кабінет у той же час містив 80 одиниць різного обладнання, хімічний 73, мінералогічний - 560, природничий - 35 (а також 65 таблиць 3 анатомії, ботаніки і зоології). Навчання природознавства відбувалося у спеціальній залі, обладнаній 2 мікроскопами, лупами, комплектом наочних анатомічних приладів. Вивченню рисунків допомагали 45 предметів-моделей (ЦДІАУЛ, Ф. 179. оп. 3, спр. 1283, арк. 56, 89 зв). Щоправда, звіт шкільного інспектора Т. Козяри (березень 1930 р.) не настільки піднесено характеризував забезпечення навчальних кабінетів обладнанням. За словами інспектора, фізичний кабінет лише в минулому році був забезпечений необхідними навчальними засобами, які виготовляв викладач фізики Теодор Матковський разом зі студентками. Біологічний кабінет був надто малим, тож навчатися в ньому могли невеликі групи семінаристок. Зали для ручних робіт у закладі взагалі не було і лише в 1929 р. її виділено та облаштовано необхідними засобами (ЦДІАУЛ, Ф. 179. оп. 3, спр. 1283, арк. 110). До послуг викладачів і студентів семінарії були бібліотеки. На середину 1928 р. у бібліотеці для викладачів містилося 320 томів, в учнівській бібліотеці - 600 томів. у березні 1930 р. бібліотечні фонди семінарії налічували 1200 томів, а в грудні 1932 р. - 1470 (ЩДІАУЛ, Ф. 179. оп. 3, спр. 1283, арк. 89зв, 110; спр. 1284, арк. 29).

Для забезпечення педагогічної практики семінарії зобов'язані були утримувати початкові школи («школи вправ»). Така школа при семінарії сестер Василіянок з'явилася у 1920 р. і діяла у приміщенні монастиря (ЦДІАУЛ, Ф. 179. оп. 2, спр. 999, арк. 154). Школа працювала як шестикласна (згодом семикласна) для дівчат, а у 1930-х рр. шестикласна коедукаційна школа з українською мовою навчання. Кількість учнів не була сталою: у вересні 1922 р. вона складала 110, у листопаді 1924 р. - 76, у березні 1930 р. - 126 осіб (ЦДІАУЛ, ф. 179. оп. 3, спр. 1283, арк. 13, 55, 111). На 1932 р. у цій школі працювали сестра Анеля Марія Ізничак як керівник і вчитель (закінчила вчительську семінарію в Яворові, вищі вчительські курси у Варшаві) та 5 жінок-педагогів: О. Дзядик, А. Хемик, Г. Радзивіл, черниці О. Молчко та Н.-В. Пилтик. До слова, і А. Хемик, і Г. Радзивіл були випускницями вчительської семінарії сестер Василіянок (ЦДІАУЛ, ф. 179. оп. 2, спр. 999, арк. 25 - 26).

Виховна діяльність в учительській семінарії сестер Василіянок зосереджувалася переважно на релігійноморальному напрямі. Як свідчить звіт директора семінарії М. Байрака від 28 квітня 1925 р., цієї справою активно займався катехит о. Северин Сапрун. Крім того, в закладі діяв гурток Пресвятої Діви Марії (Марійське товариство), до якого входили 28 семінаристок, що здійснювали відповідні релігійні практики. Більшість учениць, за твердженням директора, частіше ніж звичайно приступають до сповіді і причастя. Оскільки значна частина студенток походили з сімей учителів і робітників, то викладачі намагалися розвивати у них ті позитивні якості, які сформувалися ще у родині. Директор розповідав про проведення господинями курсів виховних бесід із семінаристками на тему поведінки в товаристві, чистоти і порядку в домі і господарстві тощо. Тричі у поточному (1924/1925) навчальному році в семінарії проводилися товариські забави з танцями. Викладачки регулярно відвідували стації і помешкання родичів студенток, щоб переконатися в існуванні домашнього нагляду та наявності гігієнічних умов (ЦДІАУЛ, Ф. 179. оп. 3, спр. 1283, арк. 63).

Водночас діяв і гурток історично-літературної самоосвіти, в якому щодругий тиждень відбувалися відчити студенток, а викладач рисунків о. С. Венгринович мав виклади з історії церковного мистецтва, М. Байрак - з всесвітньої історії. Водночас директор у згаданому звіті зауважив, що 19 учениць відвідують місцеву музичну школу, де навчаються передовсім гри на скрипці. Учениці кожну другу неділю співають у церкві під час літургій, а хор семінарії, за словами М. Байрака, користується «загальним визнанням» (ЩДІАУЛ, Ф. 179. оп. 3, спр. 1283, арк. 63 - 63 зв). 
Згідно зі звітом директора, фізичне виховання здійснювалося не лише на уроках руханки, але й у рамках пластового гуртка, що діяв в семінарії. Гуртком керувала О. Чайківська. Учениці лише в 1924/1925 н. р. здійснили вісім коротких мандрівок до найближчих околиць міста. На літо 1925 р. були заплановані більш тривалі мандрівки (ЦДІАУЛ, ф. 179. оп. 3, спр. 1283, арк. 63 зв).

У звіті за 1927/1928 н. р. директор семінарії о. Є. Громницький відзначив існування, крім Марійської содаліції, гуртка самоосвіти (полоністичного та україністичного) і дружини Пласту, ще й педагогічного гуртка, який утворили студентки 4 і 5 курсів. Вони писали реферати на педагогічні теми, виступали з відчитами, аналізували лектури та статті з педагогічних часописів, передплатили журнал «Przyjaciel szkoły». Діяла на той час і студентська «каса ощадності» (на 200 злотих). Важливо, що функціонувало студентське самоврядування, щоправда не на всіх курсах. Семінаристки відвідували сеанси кінофільмів, бували в театрі Дрогобича під час демонстрації класичних вистав, слухали вокально-музичні композиції приїжджих митців. Самі ж студентки організовували аматорські вистави, концерт на честь Тараса Шевченка (у ній взяв участь «смичковий оркестр» семінаристок). 24 червня 1928 р. на шкільному майданчику влаштовано гімнастичний «попис» студенток. Останні, крім того, взяли участь в екскурсіях до Львова, де відвідали школу глухонімих і незрячих, музеї Дзєдушицьких і мистецького промислу тощо (ЦДІАУЛ, Ф. 179. оп. 3, спр. 1283, арк. 90).

На початку 1930 р. у семінарії діяв ще й гурток «Апостольство молитви», що відзначив інспектор Т. Козяра, підкресливши водночас і позитивний факт наявності в семінарії каплички, де шкільний хор під час богослужіння співав релігійні пісні. Поза тим чиновник присвятив увагу державному (громадянському) вихованню в семінарії, яке зосереджувалося навколо офіційних урочистостей в дні державних свят (ЦДІАУЛ, Ф. 179. оп. 3, спр. 1283, арк. 111).

Задля активізації виховної роботи у семінарії в 1929/1930 н. р. було створено Раду опікунів класів, яка регулярно збиралася на засідання і обговорювала нагальні питання. Як свідчить звіт директора М. Григорійчука від 26 лютого 1930 р., в семінарії головну увагу присвячували вихованню релігійних почуттів, громадянському вихованню, формуванню почуття людської гідності, вихованню волі, сили духу, ініціативності і витривалості, ґречності, ощадності (фонд «каси ощадності» на той час становив понад 165 злотих). Було організовано «шкільний крамик» - товариську крамницю, яку провадили студентки (від 1 листопада 1929 р. до 30 січня 1930 р. для крамниці куплено товарів на 186 зл., а продано їх за 213 зл.). Виховувалося й почуття «щирої поваги до школи», єдності з нею. 3 метою співпраці семінарії та сім'ї у справі виховання молоді було засновано «Батьківський комітет» (ЦДІАУЛ, Ф. 179. оп. 3, спр. 1283, арк. $132-133$ зв).

Вочевидь за вимогою влади у семінарії на початку 1930-х рр. було утворено гурток Ліги протиповітряної та протигазової оборони, до складу якого записалися 57 студенток. Вони змушені були сплачувати грошові внески (5 - 10 грошей на місяць), але на кінець 1932 р. зібрані 9 злотих так і не передали до каси дрогобицького повітового осередку цієї організації (ЦДІАУЛ, ф. 179. оп. 3, спр. 1284, арк. 30). У той же час в закладі започатковано краєзнавчий, спортивний гуртки та гурток фізики, які майже не працювали. Натомість розвивався драматичний гурток під орудою М. Рабія, який 1932 р. влаштував чотири імпрези (зібрані кошти спрямовувалися на облаштування «світлиці» та закупівлю часописів). Здебільшого формально існувало й студентське самоврядування (ґміни курсів і ґміна закладу). Це дало підстави інспектору В. Даєвському дещо песимістично зауважити, що керівництву семінарії не вдалося оживити виховну працю в закладі (ЦДІАУЛ, Ф. 179. оп. 3, спр. 1284, арк. 31 - 32).

Успішність студенток була достатньо високою. Інспектор С. Пьотровіч, звізитувавши семінарію у квітні 1927 р., визнав достатніми навчальні досягнення майбутніх учительок, хоча висловив застереження щодо методів навчання при викладанні польської і німецької мов (ЦДІАУЛ, Ф. 179. оп. 3, спр. 1284, арк. 10 - 10 зв). За результатами ж річної класифікації у червні 1928 н. р. зі 105 студенток дуже добрі оцінки отримали 15 (14,28\%), добрі - 46 (43,72\%), достатні - 17 (16,19\%). На повторний екзамен потрапили 15 студенток, а 12 визнано нездібними. Водночас оцінки 3 виховання були високими у 82 семінаристок, поведінка решти визнана як «добра» (ЦДІАУЛ, ф. 179. оп. 3, спр. 1283, арк. 94). Під час візитації семінарії 12 - 14 березня 1930 р. інспектор Т. Козяра відзначив добрі успіхи студенток 3 математики і фізики та дуже добрі зі співу і музики. Водночас дещо розкритикував викладача педагогіки Гжегожа Банаха за надмірне дотримання підручників, непослідовне викладання психології дітей, відсутність проблемного викладу історії виховання (інспектор побажав викладачеві зосередити увагу на аналізі історичних текстів, а не лише спиратися на підручник С. Кота). Позитивні відгуки інспектора за успішне навчання студенток отримав викладач польської мови Симон Бієр, а також викладачі фізики (Теодор Матковський), біології (Роман Смалько), ручних робіт (Софія Рейхард), співу і музики (Анастасія Герник). Т. Козяра хвалив і М. Григорійчука за викладання української мови, зауваживши, що педагог вчить мислити, домагається змістовних відповідей. Незадоволення чиновника викликали лекції Михайла Рабія з історії, тож побажав викладачеві урізноманітнити форми і методи навчання, скеровувати молодь до самостійного читання історичних джерел. Дидактично слабкою Т. Козяра визнав і лекцію Дмитра Поповича з географії (ЦДІАУЛ, ф. 179. оп. 3, спр. 1283, арк. 112 - 115).

У роки наявності в семінарії прав публічності (1925/1928) навчання завершувалося іспитом зрілості, який включав виконання письмових завдань з педагогіки, польської і української мови (по три завдання з кожного предмету), а також усного іспиту з інших предметів. Цікаво, що серед завдань з української мови під час матури наприкінці травня 1928 р. випускницям пропонувалися два завдання, пов'язані з творчістю Івана Франка: 1) розвинути думку І. Франка «Пісня і праця великі дві сили, їм я до скону бажаю служить», 2) життя і творчість І. Франка: «Я ж весь вік свій, весь труд свій тобі дав у незламнім завзяттю, підеш ти у мандрівку століть з мого духа печаттю» (ЦДІАУЛ, Ф. 179. оп. 3, спр. 1283, арк. 91 - 91зв). 
У 1936 р. приватна жіноча вчительська семінарія сестер Василіянок припинила своє існування. Причина полягала у шкільній реформі 1932 р., згідно з якою учительські семінарії слід було реорганізувати в педагогічні ліцеї. Керівництво семінарії планувало створити чотирикласну гімназію нового типу, а опісля впровадити до життя педагогічний ліцей (С. Р.-К., 1973, с. 499). Перетворення семінарії на гімназію було започатковано у 1935/1936 н. р. - офіційна назва навчального закладу на той час була «Приватна жіноча гімназія сестер Василіянок у Дрогобичі» (ДАЛО, ф. 1262, оп. 9, спр. 1, арк. 5 - 5 зв). Однак ці гімназійні класи так і не отримали «права публічності» (ЦДІАУЛ, ф. 179. оп. 3, спр. 1284, арк. 35 - 36). Впровадити до життя педагогічний ліцей сестрам Василіянкам також не вдалося. Припускаємо, що на заваді стало українське обличчя закладу.

\section{ВИСНОВКИ ТА ПЕРСПЕКТИВИ ПОДАЛЬШИХ ДОСЛІДЖЕНЬ}

Отже, сестри ЧСВВ впродовж міжвоєнного періоду активно провадили в стінах монастиря дві освітні інституції - учительську жіночу семінарію та початкову школу. Їм вдалося забезпечити ці заклади матеріально, організувати належний педагогічний персонал, зібрати значну кількість семінаристок та учнів. Освітній процес визначався державними програмами і планами, виховна ж робота зосереджувалася переважно на релігійноморальному, естетичному та громадянському напрямах. За приблизними підрахунками, учительська семінарія сестер Василіянок підготувала понад 350 народних учительок, які згодом виконували педагогічні обов'язки в школах краю. Перспектива подальших досліджень полягає у вивченні діяльності учительської семінарії сестер Василіянок у Яворові.

\section{СПИСОК ВИКОРИСТАНИХ ДЖЕРЕЛ}

Галів, М., Чава, І. (2016). Середні навчальні заклади у Дрогобичі (1919 - 1939 рр.). Актуальні питання гуманітарних наук, 16, 21-32. ДАЛО - Державний архів Львівської області.

Добрянський, Б. (1995). З історії Дрогобицької української учительської семінарії сестер Василіянок. Дрогобицький краєзнавчий збірник, I, 78-82.

Добрянський, Б. (2005). Шкільництво у Дрогобичі між двома світовими війнами. Drohobycz - miasto wielu kultur, 105-115.

Завгородня, Т. (2007). Теорія і практика навчання в Галичині (1919 - 1939 рр.). Івано-Франківськ.

Тимошенко, Л. (ред). (2009). Нариси з історії Дрогобича (від найдавніших часів до початку XXI ст.). Дрогобич: Коло.

С. Р.-К. (1973). Українська Дівоча Учительська Семінарія Василіянок у Дрогобичі. Дрогобиччина - земля Івана Франка. Нью-ЙоркПариж-Сидней-Торонто. Т. 1, 496-500.

Сеньків, М. (2011). Культурно-національне життя Дрогобича у міжвоєнний період (1919 - 1939 рр.). Дрогобицький краєзнавчий збірник, XIV-XV, 338-344.

ЦДІАУЛ - Центральний державний історичний архів України у Львові.

Zagórowski, Z. (ed.) (1924). Spis nauczycieli szkół wyższych, średnich, zawodowych, seminarjów nauczycielskich oraz wykaz zakładów naukowych i władz szkolnych. Lwów-Warszawa: Książnica Polska.

\section{REFERENCES}

Haliv, M., Chava, I. (2016). Seredni navchalni zaklady u Drohobychi (1919 - 1939 rr.). Topical Issues in the Humanities, 16, 21-32.

DALO - Derzhavnyi arkhiv Lvivskoi oblasti.

Dobrianskyi, B. (1995). Z istorii Drohobytskoi ukrainskoi uchytelskoi seminarii sester Vasyliianok. Drohobych Local History Collection, I, 78-82.

Dobrianskyi, B. (2005). Shkilnytstvo u Drohobychi mizh dvoma svitovymy viinamy. Drohobycz - miasto wielu kultur, 105-115.

Zavhorodnia, T. (2007). Teoriia i praktyka navchannia v Halychyni (1919 - 1939 rr.). Ivano-Frankivsk.

Tymoshenko, L. (ed). (2009). Narysy z istorii Drohobycha (vid naidavnishykh chasiv do pochatku XXI st.). Drohobych: Kolo.

S. R.-K. (1973). Ukrainska Divocha Uchytelska Seminariia Vasyliianok u Drohobychi. Drohobychyna is the Ivan Franko's land. Niu-York-ParyzhSydnei-Toronto. Vol. 1, 496-500.

Senkiv, M. (2011). Kulturno-natsionalne zhyttia Drohobycha u mizhvoiennyi period (1919 - 1939 rr.). Drohobych Local History Collection, XIV-XV, 338-344.

TsDIAUL - Tsentralnyi derzhavnyi istorychnyi arkhiv Ukrainy u Lvovi.

Zagórowski, Z. (ed.) (1924). Spis nauczycieli szkół wyższych, średnich, zawodowych, seminarjów nauczycielskich oraz wykaz zakładów naukowych i władz szkolnych. Lwów-Warszawa: Książnica Polska. 